\title{
UBQLN2 Gene
}

National Cancer Institute

\section{Source}

National Cancer Institute. UBQLN2 Gene. NCI Thesaurus. Code C101349.

This gene may play a role in protein turnover. 